\title{
Discounting Telephone Service: An Examination of Participation in the Lifeline Assistance Program Using Panel Data
}

\author{
Janice A. Hauge* \\ University of North Texas \\ P.O. Box 311457 \\ Denton, TX 76203 \\ jhauge@unt.edu \\ Mark A. Jamison \\ University of Florida \\ P.O. Box 117142 \\ Gainesville, FL 32611 \\ jamisoma@ufl.edu \\ R. Todd Jewell \\ University of North Texas \\ P.O. Box 311457 \\ Denton, TX 76203 \\ tjewell@unt.edu
}

JEL Codes: H53, L5, L96

Keywords: Telecommunications, Welfare Participation, Lifeline, Subsidies

*Corresponding author: Tel.:1-940-565-4544; Fax: 1-940-565-4426

\begin{abstract}
We are grateful to James Prieger (Pepperdine University), Shane Greenstein (Northwestern University), Lynne Holt and Virginia Hessles (The Public Utility Research Center at the University of Florida), and Greg Shafer (Florida Public Service Commission) for helpful comments and suggestions. We also thank Mary Rose Sirianni (BellSouth), Sandy Khazraee (Sprint), Beth Salak (Florida Public Service Commission), Anne Williamson (Shimberg Center for Affordable Housing), and Thomas McCabe (TDS) for providing data, and Guillermo Sabbioni (University of Florida) for research assistance. Lastly we are grateful to BellSouth and Sprint for providing funding for this research. The authors are responsible for all errors and omissions.
\end{abstract}




\title{
Discounting Telephone Service: An Examination of Participation in the Lifeline Assistance Program Using Panel Data
}

\begin{abstract}
We examine the Lifeline Assistance Program to consider reasons people forgo a program providing financial benefits. Using panel data we employ a feasible generalized least squares estimation in which the dependent variable is the logit of the Lifeline participation rate. Our unique database incorporates characteristics of the eligible rather than the general population. We find incumbent telecommunications providers' enrollment efforts are statistically significant, and that home ownership and female head of household are associated with greater participation; being elderly and less educated are associated with less participation. Additionally, we find that an increase in the local phone rate is associated with increased participation. Our findings are important for regulatory policy surrounding the Lifeline program and universal service programs generally.
\end{abstract}




\section{Introduction}

Situations arise in which persons fail to enroll in public assistance programs even though they would financially benefit from the assistance. In this paper, we examine participation in a unique public assistance program, the Lifeline Assistance Program (Lifeline), which is a nationwide program created by the Federal Communications Commission (FCC) to provide price discounts to low-income telephone subscribers. ${ }^{1}$ The program is unusual in that utility regulators - not institutions specialized in social services - created the program and oversee it.

Furthermore, the program uses both private sector and public sector organizations to enroll participants and administer the program. Annual Lifeline discounts to low-income households nationwide in 2004 totaled over $\$ 730$ million; for the five-year period from 2000 through 2004, discounts totaled over $\$ 4.97$ billion. $^{2}$

The Lifeline program began in 1984 to help low-income households meet the expense of telephone service. By 1989, 26 states participated in this discretionary program. In an effort to promote the federal goal of universal service, The Telecommunications Act of 1996 made it compulsory for states to participate in the program, which theoretically would increase telephone penetration rates nationwide. The FCC asserted that state and federal governments are jointly responsible for ensuring low-income citizens have affordable access to telecommunications services. As such, the FCC provides a base level of federal support to all states as well as partial matching of state telecommunications discounts. States are responsible for implementing the Lifeline program, for determining eligibility requirements following the federal guidelines, and

\footnotetext{
${ }^{1}$ Technically, eligibility is determined by household, not by subscriber. For convenience, we will generally refer to subscribers when referring to household telecommunications customers.

${ }^{2}$ Data from the FCC's Monitoring Report, December 2005, Section 2.
} 
for ensuring telephone companies' compliance. The overriding goal of the Lifeline program is to ensure that people who want basic local telephone service can afford it. ${ }^{3}$

Recently policymakers and incumbent local exchange carriers (ILECs) in Florida have been concerned that the numbers used for estimating eligible households and the participation rates that are based on those numbers may be flawed and, therefore, that the strategies used to publicize the program may not be optimal. ILECs have a specific interest in Lifeline participation. ILECs in Florida requesting approval of the Florida Public Service Commission (FPSC) to increase local telephone rates must demonstrate a commitment to helping low-income households obtain telephone service. The Lifeline program is one method by which the ILECs can positively impact the low-income population, and so a thorough understanding of participation decisions is essential for them. The FCC includes Lifeline program statistics in many of its annual telecommunications reports, and many states produce individual reports. ${ }^{4}$ These reports provide excellent information on the status of the Lifeline program; however, they provide only limited analysis of factors that drive the rate of participation.

In addition to being among the first attempts to analyze the determinants of Lifeline participation, this study improves the existing literature through use of a unique database that incorporates the characteristics of the population eligible to receive the Lifeline benefit. By focusing on characteristics of the eligible households (as opposed to focusing on characteristics of all households in a geographic area), we believe that our study is better able to explain participation decisions of the subset of the population that is actually eligible to receive support.

Our results illustrate that company efforts to enroll beneficiaries are important, and that demographic measures such as ethnicity and gender are not as significant as a householder's age

\footnotetext{
${ }^{3}$ The associated Link-Up program provides a one-time subsidy to households to offset the cost of initiating telephone service. Often the Lifeline and Link-Up programs are referenced together. In our paper we focus on the Lifeline program due to its recurring benefits.

${ }^{4}$ For example, see Florida Senate (2004) for an assessment of the Lifeline program in 2004.
} 
or education level. Some telephone companies appear to experience greater levels of Lifeline participation than other companies, although the magnitudes of these effects are relatively small; specifically, BellSouth and Verizon are associated with greater Lifeline participation rates in Florida relative to smaller telephone companies. We also find that low-income households in our study increase their participation in the Lifeline program when faced with higher prices for local telephone service, and that customers decrease their participation in Lifeline when they increase their use of cell phones. This analysis presents important results for ILECs concerned with maintaining a profitable telephone rate structure and for regulators involved in evaluating rate structures. Additionally, it provides regulators with information that might be used to encourage telecommunications providers to more effectively target potential Lifeline subscribers. Finally, the analysis provides important information for policymakers interested in increasing Lifeline participation rates in Florida and nationwide, and for those interested in increasing welfare program participation generally. ${ }^{5}$

\section{Review of Related Research}

Recently the FCC and various state regulatory authorities have begun to question the effectiveness of efforts to promote the Lifeline program. As of April 2004, only one-third of eligible households in the United States actually subscribed to the program (FCC, 2004), and states vary greatly in their participation rates. In West Virginia, only 3.3 percent of eligible households participated in 2002, while in California, 131.9 percent participated. ${ }^{6}$ In Florida, participation rates are relatively low: only 12 percent of eligible households participated in 2005 (Holt and Jamison, 2006), resulting in some state pressure on telecommunications providers in Florida and the FPSC to explain and improve the situation.

\footnotetext{
${ }^{5}$ There are also concerns about the usefulness of the program for promoting universal service. We do not address this issue in this study.

${ }^{6}$ California instituted its own eligibility requirements including self-certification of eligibility, which resulted in their having greater than 100 percent of eligible households participating over the years $2002-2004$.
} 
Because a main goal of the FCC is to promote universal service, the changing telecommunications environment and states' efforts to balance a strong telecommunications investment environment with effective welfare support is important. For example, telecommunications companies' pricing decisions for basic telephone service continue to be regulated in many states. As the affordability of basic telephone service would be expected to influence participation in the subsidy program, regulation has a direct impact on Lifeline enrollment. Lack of regulation of mobile telephone pricing in the United States is also expected to impact Lifeline enrollment, as mobile providers generally are not required to participate in the Lifeline program. ${ }^{7}$ Rodini et al. (2003) illustrate this relationship between mobile and fixed line phone service. In particular, they find that fixed line and mobile services are reasonable substitutes for one another, and that subsidies to wireline carriers for universal service may be unjustified. $^{8}$

Currently, the Lifeline program is tangentially addressed in two areas of economics research: the effectiveness and importance of universal service in general, and the economics of welfare participation. Academic papers addressing federal assistance programs designed to increase telephone penetration rates (typically referred to as universal service programs) have almost unanimously determined that such programs are ineffective and/or inefficient. For example, Rosston and Wimmer (2000) find that federal universal service programs have little effect on telephone penetration rates, adversely affect the market through large taxes, and adversely affect competition. Valletti et al. (2002) add that different groups of consumers are

\footnotetext{
${ }^{7}$ Cellular providers are increasingly offering Lifeline discounts. For example, in Florida, Sprint / Nextel offers a discounted mobile phone plan to eligible low-income households. AT\&T wireless offers a similar plan in Louisiana, Mississippi, Washington, and Oregon.

${ }^{8}$ Wireline refers to the traditional method of providing telephone service, namely via telephone wires buried in the ground or strung on utility poles. This is also frequently called fixed line service because the line is not mobile, but fixed services may also be wireless. Subsidies for wireline services would be particularly unjustified if further research confirms that low-income households choose wireless telephone communications rather than wireline, all else equal.
} 
affected by universal service programs in different ways, so that determining the actual benefits to society overall is difficult.

Regarding the cost-effectiveness of Lifeline specifically, Garbacz and Thompson (1997, 2002, and 2003) find that due to small elasticities of demand for participation in the Lifeline program, extremely large expenditures per household on promoting Lifeline are required to increase the telephone penetration rate. Moreover, these effects have increased over the last decade; they find the Lifeline program to be ineffective, costly, and approximately nine times more expensive than a more targeted program might be. Similarly, Eriksson et al. (1998) focus on targeted versus untargeted subsidies in considering policies to promote universal service, and find that subsidies such as Lifeline are ineffective in the telecommunications industry.

With respect to participation in Lifeline, Burton et al. (2007) consider Lifeline participation across the US and find that bureaucratic costs and restrictions some Lifeline programs impose on supplementary services (such as call waiting and caller ID) discourage enrollee participation. They consider the outreach efforts of incumbent telecommunications providers as well as enrollment procedures and eligibility criteria to show that the traditional explanations for lack of participation (rooted in stigma) may not hold for the Lifeline program. While their paper informs our study and complements our results, differences in our works exist because Florida is not subject to many of the criteria included in Burton et al.'s study. ${ }^{9}$ In a US study more complementary to theirs, Hauge et al. (2007) also find that demographics, socioeconomic factors, and service by specific traditional telephone companies affect Lifeline participation rates. These papers begin to bridge the gap between the usefulness of universal

\footnotetext{
${ }^{9}$ For example, within our study the enrollment procedures are equivalent across participating telephone companies. Additionally, there are no restrictions on supplementary services so that recipients can subscribe to call waiting, caller ID, and similar additional features while receiving Lifeline. Finally, the level of benefit is consistent throughout the state. Burton et al. incorporate each of these cross-state differences in their paper; however, these differences are not relevant to our work.
} 
service (and therefore the Lifeline program) and the economics of welfare participation. They do not, however, address the particular participation decisions of the population for whom the program is designed.

There is a large literature on participation in public assistance programs. Currie (2004) summarizes the literature with respect to the largest means-tested programs in the US. Research on participation in Food Stamps, Federal Public Housing Assistance (FPHA), Medicaid, the National School Lunch program (NSL), Supplemental Security Income (SSI), and Temporary Assistance for Needy Families (TANF) is particularly relevant for our research, given that these welfare programs are frequently used to prove eligibility for Lifeline. Studies of participation in other welfare programs guide our empirical model and serve as useful references for predicting our results. Generally, the papers find that participation in welfare programs increases with the size of the entitlement, receipt of another welfare benefit, single parenthood, and the number of children. Participation falls with age, education, income level, urban living, white head of household, and work experience. Additionally, many studies searching for drivers of participation rates take into account intangible factors such as stigma and lack of information regarding the program, both of which would decrease participation in welfare programs (see Moffitt, 1983 and Hauge et al., 2007).

Some research supports theories that either lack of information or simply a choice not to participate are dominant effects on participation in welfare programs. After their review of the main empirical studies of welfare participation, Andrade et al. (2002, p. 310) conclude: "It seems clear that non-participation in welfare programs is, indeed, in most cases, the result of a choice." However, there is a lack of theoretical research more formally addressing the issue. With respect to lack of information, we have some limited evidence. The Public Utility Research Center at the University of Florida (PURC) conducted four surveys analyzing various aspects of participation 
in Lifeline in Florida. ${ }^{10}$ These include interviews of Floridians in person and over the telephone, as well as written surveys of households that qualify but do not participate and those that qualify and had disconnected their telephone service. Lack of information was shown to be a main indicator of non-participation in Lifeline in Florida. Because telephone companies are responsible for notifying customers of the availability of Lifeline, we expect lack of information to be reflected in the telephone company variables used in our empirical analysis. Additionally, we expect lack of information to dominate any stigma effect and therefore program participation to be primarily dependent on telephone companies' ability to effectively enroll participants. ${ }^{11}$

\section{Structure of the Lifeline Program in Florida}

Florida began participating in the Lifeline program in 1994. The FCC establishes guidelines for Lifeline and provides some funding; however, each state develops its own policies consistent with those guidelines. Within each state, individual telecommunications carriers have leeway in the administration of the program such as how they promote it. Under the FCC guidelines, there are four tiers of monthly federal Lifeline support. The first tier of federal support is a credit (currently $\$ 6.50$ per month) available to all eligible subscribers; this represents a waiver of the federal subscriber line charge. ${ }^{12}$ The subscriber line charge is a per line charge implemented by the FCC to recover the interstate portion of telephone company costs for basic

\footnotetext{
${ }^{10}$ These surveys are available at www.purc.ufl.edu. In sum, the surveys found that lack of awareness and distrust of support programs for low-income households are significant barriers to enrollment. They also found that 88 percent of low-income households in Florida had wireline phones, about 50 percent had a cellular phone, about 50 percent had Internet access, and about 50 percent had either cable television or Direct Broadcast Satellite service.

${ }^{11}$ We expect any stigma effect to be small. First, it is simple for participants to apply and they need not do so in person. Florida provides information on Lifeline in a customer's bill, along with a form requesting that the potential participant respond if he receives any of the other welfare programs which qualify him to receive Lifeline or to submit documentation of low-income. The potential participant does not need to visit an agency or deal with social workers, nor does he have to publicly claim this benefit; it simply appears as a credit on his telephone bill each month. Such anonymity should decrease the stigma effect. Also, if the marginal disutility of enrolling decreases with participation in another program and if the primary way of qualifying for Lifeline is by showing receipt of other welfare, it seems logical that the cost of enrolling in Lifeline should be lower than the cost of enrolling in other welfare programs.

${ }^{12}$ These funds come from fees assessed on telecommunications providers.
} 
telephone lines. The second tier of federal support is a $\$ 1.75$ monthly credit also available to all eligible subscribers; this represents a reduction in the price of basic local telephone service and is available given the approval of the FPSC. The third tier of federal support is one-half the amount of additional state support up to a maximum of $\$ 1.75$ per month in federal support. Because Florida's eligible telecommunications carriers provide an additional $\$ 3.50$ per month credit to Lifeline customers' bills, Florida Lifeline subscribers currently receive a total monthly credit of up to $\$ 13.50$, consisting of up to $\$ 10.00(\$ 6.50+\$ 1.75+\$ 1.75)$ in federal support and $\$ 3.50$ in support from the telephone company that is providing service. The monthly credit increased from $\$ 13.00$ in 2003 to $\$ 13.50$ in 2004, and remained unchanged in $2005 .{ }^{13}$ The fourth tier of support, available only to eligible subscribers living on tribal lands, provides an additional credit up to $\$ 25$ per month. This amount is limited to the extent that the credit does not bring the basic local residential rate below $\$ 1$ per month. Florida has no tribal lands eligible for the Lifeline program. A telephone subscriber may receive a lesser credit if the subscriber's bill for basic local telephone service is less than the maximum available credit. ${ }^{14}$ At no time is the customer's bill for local service less than zero. Additionally, pursuant to Section 364.105 Florida Statutes, Florida's eligible telecommunications carriers must offer residential customers who are no longer eligible for Lifeline a 30 percent discount off the rate for basic local service for up to a year after their eligibility for Lifeline ceases.

To increase eligibility and participation nationwide, in 2005 the FCC expanded the federal default eligibility criteria. Nationwide, the FCC income-based criterion was raised from

\footnotetext{
${ }^{13}$ All ILECs are designated eligible telecommunications carriers; they provide Lifeline and are entitled to receive Federal support. Eligible telecommunications carrier status may also apply to wireless service providers whose petitions for such status have been approved by the FCC and to competitive local exchange carriers whose petitions have been approved by the FPSC. To date, the FCC has designated three wireless providers to serve as eligible telecommunications carriers in Florida - Nextel Partners, Sprint, and Alltel. The FPSC has designated two competitive local exchange carriers, Knology and Budget Phone, as eligible telecommunications carriers in Florida.

${ }^{14}$ Basic local telephone service includes unlimited local area calling. The Lifeline program does not prohibit consumers from purchasing additional services such as call waiting or caller ID if they wish.
} 
125 to 135 percent of the Federal Poverty Guideline (FPG). Also, two federal means-tested programs were added: NSL and TANF. Florida's eligibility criteria, like the federal default eligibility criteria, currently include TANF, Medicaid, Food Stamps, SSI, FPHA, Low-Income Home Energy Assistance Program (LIHEAP), Bureau of Indian Affairs Programs, NSL, and the income-based criterion. ${ }^{15}$ In the spring of 2005, Florida also adopted the 135 percent FPG criterion for BellSouth, Sprint, and Verizon. Lastly, the FCC required states to adopt certain certification and verification procedures and outreach guidelines for increasing participation in the Lifeline program. ${ }^{16}$

Proving eligibility is the responsibility of Lifeline subscribers in Florida. In February 2005, the FPSC entered into settlement agreements with BellSouth, Sprint, and Verizon, under which the companies agreed to implement a simplified certification process. To get a Lifeline discount, subscribers must sign under penalty of perjury that they participate in one of the Lifeline eligible programs and must identify that program or verify low-income status.

Consistent with the FCC's order, the companies are to verify annually the continued eligibility of a statistically valid sample of their Lifeline subscribers.

PURC estimates that in 2005, approximately 1.16 million Floridians were eligible for the Lifeline and Link-Up programs. ${ }^{17}$ This estimate was based on eligibility of 125 percent FPG. Under the FCC's new income-based criterion of 135 percent, approximately 1.25 million

\footnotetext{
${ }^{15}$ The federal default eligibility criteria are used if a state does not establish its own eligibility criteria. Prior to this FCC decision, the federal default eligibility criteria required the customer to participate in at least one of the following federal programs: Medicaid, Food Stamps, SSI, FPHA, or LIHEAP (or to have income $125 \%$ FPG). Small ILECs in Florida do not use the NSL program as an eligibility criterion for Lifeline.

${ }^{16}$ The small ILECs may choose to remain at 125 percent FPG. The 135 percent criterion became effective by the end of 2005. With respect to the new certification and verification procedures and outreach guidelines, Florida's ILECs were in compliance.

${ }^{17}$ Link-Up is the federal program providing a credit for telephone hook-up service. Often the Lifeline and Link-Up programs are referred to simultaneously as they have the same goal of increasing telephone penetration in lowincome areas. The primary difference is that Lifeline is a monthly credit, whereas Link-Up applies only at telephone installation. This study addresses only the Lifeline program.
} 
Floridians were estimated to be eligible. ${ }^{18}$ This means that Florida's combined participation rate for Lifeline and Link-Up was approximately 13.2 percent (FPG 125\%), or 12.2 percent (FPG $135 \%$ ), which is less than one-half the FCC's estimated national participation rate of 38 percent (FPSC, 2004). By both FPSC estimates and estimates based on data provided directly by incumbent and competitive local exchange carriers, participation rates in the Lifeline program in Florida are low relative to many other states' participation rates. ${ }^{19}$

\section{Methodology and Data}

To analyze Lifeline participation rates, this study uses a theoretical model of household utility maximization and an empirical model that includes measures of demographic factors for eligible households at the county-level and company-specific measures to ascertain the determinants of the Lifeline participation rate. Assume that household $i$ located in county $j$ maximizes per period utility, given in equation (1), subject to the budget constraint given in equation (2).

$U_{i j}=U\left[T_{i j}, Z_{i j}\right]$

$I_{i j}=\left(P_{j} \times T_{i j}\right)+Z_{i j}$

Utility is a function of telephone subscription $(T)$ and consumption of a composite good $(Z)$, where $U\left[T_{i j}, Z_{i j}\right]>U\left[0, Z_{i j}\right]$ for $T_{i j},>0$, and $\mathrm{U}_{\mathrm{Z}}>0$ and $\mathrm{U}_{\mathrm{ZZ}}<0 . T_{i j} \in\{0,1\}$; the household faces a discrete choice to subscribe to telephone service or not to subscribe. ${ }^{20}$ Income $(I)$ and the price of telephone subscription $(P)$ are exogenous, and the price of the composite good is normalized to one. Further assume that this household is eligible for the Lifeline program, which allows the household to purchase a fixed amount of telephone service at a discounted price. The price of

\footnotetext{
${ }^{18}$ Statistics are available at http://www.purc.ufl.edu/Lifeline2.htm.

${ }^{19}$ Twenty-five states had higher participation rates than Florida during the years of our study (Hauge et al., 2006); while Florida's actual participation rate of $17.57 \%$ places it at the median, Florida's participation rate is below the national average participation rate of $23.16 \%$.

${ }^{20}$ Qualifying households receive the Lifeline discount on only one telephone line. Therefore second connections and prices for second connections are part of the composite good $\mathrm{Z}$.
} 
telephone service when receiving the Lifeline benefit is the difference between $P$ and the amount of the discount $(S)$. In addition, it is possible there is some degree of stigma attached to Lifeline participation that may be a function of income and other individual characteristics. Moffit (1983) defines such stigma as "disutility arising from participation in a welfare program," which allows the inclusion of any non-monetary disutility associated with participating in a welfare program. This more general idea is useful for our purposes. Assume the non-monetary disutility cost $(C)$ must be subtracted from a household's utility if the Lifeline subsidy is accepted, and assume that this cost can vary across households.

Under the above assumptions, utility maximization implies the following decision rule for Lifeline participation:

$$
\begin{gathered}
\text { participate if } \quad U\left[T_{i j}, I_{i j}-\left(P_{j}-S\right) \times T_{i j}\right]-C_{i j} \geq U\left[T_{i j}, I_{i j}-P_{j} \times T_{i j}\right] \text { and } \\
U\left[T_{i j}, I_{i j}-\left(P_{j}-S\right) \times T_{i j}\right] \geq C_{i j} \text {, and }
\end{gathered}
$$

do not participate otherwise.

We assume a utility gain from Lifeline participation for most eligible households, with the exceptions being those households with high non-monetary costs of participation. Given that we expect direct stigma costs to be low on average, our model predicts that most households will participate, an outcome not supported by the data. One possible explanation of this can be found in the previously mentioned PURC surveys. These surveys reveal a lack of information about the program to be a main reason for non-participation. For simplicity, assume that program knowledge $(K)$ is a continuous variable ranging from zero to one, and equal to one if a household knows about the Lifeline program and equal to zero if the household is uninformed. The addition of program knowledge changes the utility maximizing rule to the following:

$$
\begin{array}{ll}
\text { participate if } & K_{i j} \times\left\{U\left[T_{i j}, I_{i j}-\left(P_{j}-S\right) \times T_{i j}\right]-C_{i j}\right\} \geq U\left[T_{i j}, I_{i j}-P_{j} \times T_{i j}\right] \text { and } \\
& K_{i j} \times\left\{U\left[T_{i j}, I_{i j}-\left(P_{j}-S\right) \times T_{i j}\right]\right\} \geq C_{i j} \text { and }
\end{array}
$$


do not participate otherwise.

Thus, a household will choose to participate in Lifeline if and only if the utility associated with participating is greater than or equal to the utility associated with not participating and if and only if the household is aware of the program. ${ }^{21}$

Equation (4) implies an ambiguous effect of $P$ on the probability of Lifeline participation. While the first inequality implies participation is increasing in $P$ since any increase in the price of telephone services makes the Lifeline subsidy more valuable, the second inequality implies participation decreases with $P$ as a higher price for telephone services causes households to not purchase service at all (i.e., these households drop off the network entirely). We expect a higher price for telephone subscription to increase Lifeline participation if low income households tend to already have telephone service before deciding to participate in Lifeline, and we expect a higher price to have the opposite effect if the Lifeline discount is insufficient to keep all subscribers on the network who had subscribed before the price increase. Also, since any increase in $S$ makes the Lifeline program less expensive, the probability of Lifeline participation is increasing in the amount of the Lifeline subsidy. Furthermore, any increase in non-monetary disutility costs decreases the utility associated with participation; thus, Lifeline participation is decreasing in $C$. Finally, program knowledge is an important determinant of the decision to participate, and anything that increases program knowledge will increase the probability of Lifeline participation. From these initial premises we put forward two propositions.

\footnotetext{
${ }^{21}$ Burton et al. (2007) include an explanation in which the consumer surplus of various households is modeled to illustrate households for whom the level of benefit is relevant. Specifically, they illustrate that there are some households who are not willing and able to sign up for telephone service at all given a particular benefit level. There are other households who are willing and able to sign up for telephone service given that same level of benefit, and those who will subscribe to telephone service without Lifeline (even if they qualify). It is this category of eligible households whose decision not to subscribe is in question.
} 


\section{Proposition 1: Lifeline program participation will vary by incumbent.}

Incumbent telecommunications providers are responsible for informing consumers of the Lifeline program. Therefore, knowledge of the program depends directly on the outreach, enrollment, and notification activities of those companies. Over the course of our study, BellSouth, Sprint, and Verizon engaged in intensive publicity campaigns not undertaken by other providers: each school-aged child received information in his or her school "welcome" package of information to be brought home at the beginning of the academic year; sign-up forms were included in each telephone bill upon connection; and welfare agencies maintained a supply of their sign-up forms to be distributed with other materials to persons applying for other welfare such as TANF and SSI. Our model predicts eligible household participation will be greater for the carriers conducting such publicity campaigns.

Proposition 2: Lifeline program participation will increase as non-monetary disutility falls. This disutility varies by socio-demographic characteristics.

Included in our category of non-monetary disutility is traditional stigma as recognized in welfare participation literature, and also characteristics of households that may cause them to disfavor participation in welfare programs. We assert that these characteristics may include gender, race, age, and education, among other intangible factors peculiar to a household.

It is these two propositions we propose to test empirically. Specifically, we ask: given the local telephone rate and the Lifeline benefit level, what types of households will choose to participate in the Lifeline program and what if anything can companies do to affect such participation. $K$ and $C$ then are of primary interest in determining household participation in the Lifeline program. We use the incumbents as proxies for $K$, and various socio-demographic characteristics of households to account for $C$. A finding that our incumbent variables are significant would support Proposition 1; a finding that our socio-demographic variables are 
significant would support Proposition 2.To test the propositions, we label the utility difference in equation (4) $y_{i j}$, and assume it takes on a linear functional form, so that the decision rule becomes the following:

participate

if $y_{i j}=x_{i j}+e_{i j}$ and

do not participate otherwise.

With household-level data, the vector of household-level parameters $\gamma$ is normally estimated using either probit or logit, depending on the assumed distribution of $e$. Furthermore, the matrix $x_{i j}$ of exogenous variables would include income, the amount of the Lifeline subsidy, the price of telephone services, non-monetary disutility, and knowledge of the Lifeline program, as well as measures that impact utility through the marginal utility of Lifeline participation relative to nonparticipation and the marginal utility of income. However, we do not observe household Lifeline choices in our data. Instead, we observe the number of Lifeline households that participate out of the number eligible within each Florida county. ${ }^{22}$ Although we do not observe household decisions, we can use the utility maximization model discussed above to motivate our countylevel empirical analysis. If the data are generated in the manner given in equation (5), then the determinants of Lifeline participation at the county level will be the determinants at the household level (i.e., components of the matrix $x_{i j}$ ) aggregated up to the county level. Note that although the determinants at the county level are assumed to be the same as the determinants at the household-level, the coefficients from our county-level analysis cannot be interpreted as household-level effects due to aggregation issues. Specifically, we cannot recover the vector $\gamma$ of household-level parameters.

\footnotetext{
${ }^{22}$ The number of Lifeline participants is provided by each company at the city level. We aggregate to the county level to correspond to the level of the eligible household data.
} 


\section{Dependent Variable}

As discussed above, Lifeline subscribers choose to subscribe on an individual household

basis; however, our data set measures the sum of these decisions at the county level. Specifically, we observe the number of positive outcomes (Lifeline subscribers) based on a total number of potential positive outcomes (eligible households). Thus, our outcome variable is grouped in percentage terms: the number of subscribing households divided by the total number of eligible households. Models with grouped data are normally estimated with weighted least squares. Weights are needed to account for the heteroskedasticity associated with observations being clustered by county. We employ a minimum logit chi-square specification in which the dependent variable is the logit of the Lifeline participation rate, i.e., the natural log of the Lifeline participation rate divided by one minus the Lifeline participation rate (Maddala, 1983, p. 30; Papke and Wooldridge, 1996, p. 620; Greene, 2003, p. 687). ${ }^{23}$

We construct our model using a complete panel of observations on all 67 Florida counties for the years 2003 through $2005 .^{24}$ The panel nature of the data allows us to use a random effects estimator. ${ }^{25}$ In the random effects model, county-specific effects measuring unobservable county

\footnotetext{
${ }^{23}$ The weights are $1 /\left[n_{i} p_{i}\left(1-p_{i}\right)\right]$, where $n_{i}$ is the total eligible households of county $i$, and $p_{i}$ is the logit probability of the Lifeline participation rate in county i. As discussed by Greene (2003, p. 677-688), $p_{i}$ must be estimated since it is a function of unknown parameters. Following the prescribed procedure, we estimate $p_{i}$ using ordinary least squares (OLS) in a first stage because all that is needed is a consistent estimate of $\mathrm{p}_{\mathrm{i}}$. The weights are then computed and used in a second-stage feasible generalized least squares estimation. Several specifications of the dependent variable are available. We choose the minimum logit chi-square estimator due to its similarity to the well-known logit dichotomous choice model. To test robustness, we estimated the model using another commonly employed specification in which the dependent variable is simply the log of the participation rate, finding no major differences between the two specifications. There are 13 year/county observations with zero subscribers. Rather than delete these observations, the number of subscribers is arbitrarily assigned to one in order to compute the dependent variable. Although clearly ad hoc, this solution is the most viable in our situation. We also include a dummy variable in our estimation to account for the 13 observations; the dummy variable (not reported for brevity) is significantly negative.

${ }^{24}$ Some county-level Lifeline participation data are available back to 2000; however, prior to 2003 data is incomplete. We choose to analyze the most-recent three years since they represent complete panels. Summary statistics for 2000-2005 are available from the authors.

${ }^{25}$ A Hausman test indicates that the assumption of the random effects model concerning the orthogonality of the random effects and the regressors is appropriate. The chi-square statistic (15 d.f.) is 20.88 , which is insignificant at any conventional level. Thus, we cannot reject the null of no correlation between the random effects and the
} 
characteristics are modeled and estimated as being randomly distributed across counties. Our random effects specification is given in equation (5), where $j$ indicates county, $t$ indicates year, and $\rho$ is the Lifeline participation rate.

$$
\ln \left(\rho_{j t}\left(1-\rho_{j t}\right)\right)=\alpha+X_{j t} \beta+\left(u_{j}+\varepsilon_{j t}\right)
$$

The time-invariant, county-specific effect $\left(u_{j}\right)$ is modeled and estimated as part of a wellbehaved, normally distributed error term $\left(u_{j}+\varepsilon_{j t}\right)$. The matrix $X_{j t}$ contains household and county measures for county $j$ in year $t$, and the vector $\beta$ and the constant term $\alpha$ represent parameters to be estimated. The equation is estimated using weighted feasible generalized least squares (FGLS), allowing the variance of $u$ to vary by counties to control for heterogeneity across panels (Greene, 2003, pp. 293-298). ${ }^{26}$

\section{Matrix $X_{j t}$ of Explanatory Variables}

Given the assumption concerning generation of the Lifeline participation data, the determinants of county-level participation rates should be the same measures included in matrix $x_{i j}$ of equation (5), aggregated to the county level. Thus, the matrix $X_{j t}$ of exogenous variables will include county-level measures that are expected to impact household utility maximization, either through the effect on the marginal utility of income, on the price of Lifeline participation, on program knowledge, or on the marginal utility of Lifeline participation relative to other options. Since the participation rate is a ratio of participating households to eligible households, the matrix $X_{j t}$ must also include measures expected to impact variations in the number of eligible households by county. The explanatory variables can be split into three categories: measures of

regressors. Complete results of this test are available from the authors. We choose the random effects model because it allows the inclusion of time-invariant regressors and is more efficient than a fixed-effects model.

${ }^{26}$ The error term ${ }_{j t}$ might be serially correlated. The standard errors for the estimation may be affected and should be viewed with some caution. 
the telecommunications environment; characteristics of the eligible population; and county-level socioeconomic characteristics.

In the first category, we include a series of variables measuring the percentage of each county's telecommunications service that is provided by each company. This allows an estimate of a provider-specific effect for BellSouth, Sprint, and Verizon relative to all other carriers. ${ }^{27}$ The provider-specific variable is denoted by the provider's name. For example, the variable Percent BellSouth indicates the percentage of the county's total telecommunications service that is provided by BellSouth. That percentage is determined by weighting BellSouth's presence in the county by the number of access lines BellSouth has in each county for each year. We expect the provider-specific variables to pick up much of the effect of program knowledge on participation.

Given existing research and our theoretical model, we expect the local telephone rate to affect Lifeline participation; Local Phone Rate is the average monthly charge within a county for a single, residential line, which should affect the participation decision since higher rates make telecommunications service more costly for households. This has two potential impacts on Lifeline participation. One the one hand, the higher price increases the value of the Lifeline discount (the gain in utility for a poor household receiving an additional dollar is greater than the gain in utility for a wealthy household receiving an additional dollar.). This situation is represented in the first inequality in equation (4). ${ }^{28}$ Studies of welfare participation

\footnotetext{
${ }^{27}$ The telecommunications environment measures are gathered from the FPSC's "Annual Report to the Florida Legislature on the Status of Competition in the Telecommunications Industry in Florida" from which the number of access lines per company and the local single residential line rate per exchange were obtained, and cell phone subscribership per county was provided directly by staff at the FPSC. The excluded category includes smaller providers: Alltel, Frontier Communications of the South, ITS Telecommunications, Northeast Telephone Company dba NEFCOM, and TDS Telecommunications/Quincy Telephone.

${ }^{28}$ Taxes are not included in the Local Phone Rate variable. This means Local Phone Rate ranges from $\$ 6.30$ to $\$ 12.10$ with a mean of $\$ 9.80$. Taxes may include Federal/State Subscriber Line charges, Universal Service Fund charges, Primary Interexchange Carrier Charges, and Local Number Portability charges. As explained in the description of the origins of Lifeline credits, the Lifeline subsidy is designed to remove these taxes from bills of
} 
overwhelmingly support the assertion that more valuable entitlements increase the probability of participation in a welfare program (Andrade et al., 2002). On the other hand, basic economic theory holds that when the price of a good increases the quantity demanded for that good falls. This situation is represented by the second inequality in equation (4) and the result of these two opposite effects is ambiguous.

While studies analyzing cell phone usage as substitutes or complements for landline phones differ in their conclusions, we assert that counties with greater cell phone usage should have lower Lifeline participation rates since a cell phone is in practice considered to be a good substitute for a landline phone (Rodini et al., 2003) and, according to a survey of Florida lowincome households, nearly 47 percent of those without wireline phones have cellular phones. ${ }^{29}$ Moreover, we assert that among the low-income population, the ability to regulate monthly expenditures is particularly important and the use of pre-paid cellular plans that serve to limit over-expenditure might be viewed favorably. Our assertions are supported in a recent study by Tucker, Brick and Meekins (2007) that shows landline and cellular phones more likely to be substitutes than complements for those of younger age, races other than White, and lower education, characteristics found to be associated with low-income households. To account for these possibilities, we measure cell phone usage on a county-wide, per household basis (Cell Phones).

With respect to the second category of explanatory variables, characteristics of the eligible population, we expect socioeconomic characteristics of eligible households to influence the Lifeline participation rate. For this type of explanatory variable, we employ information from

eligible participants; thus, eligible households should pay only the local phone rate. While our theoretical model references a price of Lifeline that includes the subsidy, the subsidy does not vary by county. Therefore, it is appropriate to include Local Phone Rate as the proxy for price. Also, the Lifeline subsidy is not included in the estimation.

${ }^{29}$ Mark Jamison, Presentation to the Florida Public Service Commission, February 27, 2006, available online at www.purc.ufl.edu. 
the University of Florida's Shimberg Center for Affordable Housing, which includes the number of households and the characteristics of households that qualify for Lifeline. Note that these measures reflect the distribution of characteristics within the eligible population, not necessarily within the county as a whole, and that these measures vary by county and by year. The use of characteristics of eligible households is a unique aspect of this study, allowing us to contribute to the literature by focusing on characteristics of households the program is specifically designed to assist as opposed to characteristics of a geographically defined area.

We expect that housing tenure will be a significant determinant of the Lifeline participation rate; therefore, we control for the percentage of eligible households that own their home (Percent Own Home) versus renting. If homeowners are more vested in housing services and move less often, then it is reasonable to believe that increased homeownership would lead to increased participation. Education level may influence the participation rate if more educated individuals have an easier time finding, understanding, and enrolling in benefits programs. Conversely, if welfare stigma is a dominant determinant of participation, we would expect the participation rate to decrease with education as associations with more highly educated persons would discourage peers from applying for welfare. ${ }^{30}$ We control for the percentage of heads of eligible households who did not finish high school (Percent No High School) and the percentage that has finished high school but has no further education (Percent High School), with the excluded category more than high school education. Studies evaluating participation in welfare programs have concluded that participation falls with education; however, we are unable to predict the effect of education due to contradictory participation incentives.

\footnotetext{
${ }^{30}$ This is termed "peer group stigma effect" by Blundell et al., 1998, who argue that associating with more educated individuals leads one to believe that he or she should not need public assistance but should be intelligent and motivated enough to provide for oneself. Therefore while more educated people might know of the Lifeline program, they might believe that it is for those unable to provide for themselves, not for well-educated individuals with skills to support themselves.
} 
Various household characteristics may be associated with a greater propensity to enroll in public assistance programs, as prior studies have shown such characteristics to affect costs and preferences (Blundel et al., 1988; Blank and Ruggles, 1994; Hoynes, 1996). We expect that race and gender of the head of the household will have an impact on the Lifeline participation rate, so we control for the percentage of eligible household heads that are white (Percent White, with excluded category all other races) and the percentage of heads of households that are female (Percent Female). We expect Lifeline participation to be positively correlated with the percentage of the population that is female since many studies have found that single-parenthood is more frequently a determinant of participation, and most single parents are women. ${ }^{31}$ The age of the head of eligible households should influence the Lifeline participation rate, so we include age category percentages (Percent Age 25-54, Percent Age 55-74, Percent Age 75+), with excluded category below age 25 . Results of prior studies generally find that participation in welfare programs declines with age (Blundell et al., 1988; Stuber and Kronebusch, 2004). We might expect a positive correlation between age and participation given the assumed lower transaction costs of enrollment among the elderly; however, a combination of lack of knowledge about the program, stigma associated with welfare, and perceived lack of need for the subsidy lead us to predict a negative effect.

The third category of explanatory variables includes county-level socioeconomic measures that are expected to influence the Lifeline participation rate. Unlike the county-level, eligible household explanatory variables discussed above, these measures describe all households in the county, are constant over time, and represent the year 2000. Counties with more rural inhabitants (Percent Rural) may differ from urban counties. An eligible rural household should be more likely to enroll due to a lack of substitutes for phone service such as

\footnotetext{
${ }^{31}$ Approximately 9.8 million of 11.9 million single parents in the US are women (www.singleparent.com).
} 
family or friends with telephone service in close proximity. On the other hand, rural households may have limited knowledge of the program since many outreach activities are centered in more urban areas. Finally, poor counties may differ from rich counties in terms of Lifeline participation; we capture this effect with the percentage of households receiving government assistance (Percent Welfare). Prior research has found that participation in welfare programs is higher in states with relatively more recipients of any government assistance program (McGarry, 1995; Yelowitz, 2000). Because of the manner in which Lifeline participants frequently prove eligibility (by proving receipt of another welfare program), we expect participation in the Lifeline participation rate to be positively correlated with the percentage of the population receiving some form of government assistance. Table 1 presents summary statistics for the variables used in this study.

\section{[INSERT TABLE 1]}

\section{Results}

The results of the weighted FGLS estimation of equation (5) are presented in Table $2 .{ }^{32}$ Due to the non-linear construction of the dependent variable, the coefficients cannot be interpreted as marginal effects of the independent variables on the Lifeline participation rate. In non-linear estimations, there are two methods commonly used to produce marginal effects: compute the marginal effects at sample means, or simulate marginal effects. We simulate marginal effects by changing the relevant independent variable by one percent and comparing the pre-change and the post-change predicted participation rates using the coefficients from Table 2. In this way, we can compute the marginal effects and report them in elasticity terms. Specifically, the reported marginal effects are interpreted as the percentage change in the

\footnotetext{
${ }^{32}$ The model also includes yearly dummies (coefficients are not reported for brevity) to indicate a time trend in Lifeline participation that is common to all counties. The results (available from the authors) indicate that a positive shift in the participation rate occurred after 2003.
} 
participation rate associated with a one percent change in the independent variable (i.e., the elasticity of Lifeline participation with respect to the independent variable).

\section{[INSERT TABLE 2]}

With respect to measures of the telecommunications environment, the results indicate that service by BellSouth or Verizon has a statistically significant effect on the Lifeline participation rate. However, the marginal effects imply that Lifeline-eligible customers of these companies are only slightly more likely to subscribe than customers of other telecommunications providers. Sprint does not have a systematically higher or lower participation rate than the small local exchange carriers. ${ }^{33}$ This result supports our Proposition 1, although weakly. Since our estimation controls for observable and unobservable county-specific measures, these results could suggest that the efforts of BellSouth and Verizon to enroll subscribers do serve to differentiate them from the smaller telephone companies and that these marketing efforts may be somewhat effective.

Local Phone Rate is a significantly positive determinant of the Lifeline participation rate; in addition, demand for Lifeline service is inelastic with respect to changes in the local telephone rate. This result suggests that the effect of the first inequality in equation (4) dominates the second effect. This result implies that the magnitude of the increase in price in our model encouraged more eligible households to participate in Lifeline rather than encouraging more households to disconnect telephone service entirely. ${ }^{34}$

\footnotetext{
${ }^{33}$ We report the Wald chi-square test statistic on the three provider variables: chi2 $(3)=81.86$, Prob $>$ chi2 $=$ 0.0000 , indicating that the coefficients are jointly significant at the $1 \%$ level.

${ }^{34}$ The positive coefficient for Local Phone Rate may also be due to omitted variable bias. It has been suggested that such a result could occur if telephone service is more valuable to low-income households in counties where the local phone rate is higher, and therefore more eligible households subscribe to Lifeline service rather than declining all service. Additionally, the positive correlation between Local Phone Rate and the population-weighted average local calling area in a county $(0.5215)$ may contribute to this result.
} 
As expected, and in agreement with the findings of Rodini et al. (2003) and Tucker et al. (2007), we find that counties with more cell phone usage have lower rates of Lifeline participation although the effect is small. Cell phone usage appears to serve as a substitute for landline phones among the low-income population studied, leading to a negative correlation between Cell Phones per household and the Lifeline participation rate.

With respect to characteristics of the eligible population, the socioeconomic characteristics of eligible households are generally found to influence the Lifeline participation rate. These results support our Proposition 2. Owning one's home (Percent Own Home) as opposed to renting has a positive and relatively large effect on participation. This is intuitively logical: as people invest in homeownership, ties to the community by which one might learn of the Lifeline program increase. Additionally, the disutility associated with signing up for the Lifeline program for a homeowner would be incurred only once. Since the Lifeline subsidy is provided only upon connecting phone service, a renter might not choose to incur the costs of signing up, assuming that he or she may be relocating in the near future and may then have to sign up again.

The coefficients on Percent No High School and Percent High School are negative, implying that college-educated heads of households tend to sign up for Lifeline more often than less-educated heads of households. This positive relationship between education and Lifeline participation suggests that the ability to learn about and understand the program is a significant factor in determining the participation rate. Percent Female is positive and significant, which is consistent with our predication. In addition, the Lifeline participation rate is elastic with respect to female heads of households. Of the age categories, only Percent Age 75+ is significant and 
negative, an unsurprising result given that participation in welfare programs is frequently found to decrease with age. Furthermore, race is not found to be a significant factor. ${ }^{35}$

With respect to county-level socioeconomic characteristics, counties with more rural populations have lower Lifeline participation rates although the marginal effect is not large. Rural households typically do not have the breadth of available substitutes that urban households do; therefore, they might be expected to sign up for landline service and subsequently Lifeline more than similar urban households. The fact that they do not indicates that they may be unaware of the program. Companies interested in increasing participation are likely to focus their outreach efforts where they can reach the most people at least cost; this would generally occur in more urban areas. Additionally, information regarding the Lifeline program is often located in welfare offices, which are generally in urban areas. This result should be of primary interest to regulators as one of the main goals of the Lifeline program is to advance universal service by promoting affordable telephone access to consumers residing in rural areas. ${ }^{36}$ The fact that rural households are less likely to participate when they are the intended beneficiaries of the program suggests that companies' efforts to increase participation may not be correctly targeted. While it may be good business practice for companies to attempt to reach as many people as possible at the lowest possible cost, such a strategy may be missing those households the program is most concerned with helping.

\footnotetext{
${ }^{35}$ In other versions of the model, we control for percent white, percent black, percent Hispanic, and all other races. The results (available from the authors) show insignificant coefficients on all racial categories. As an analysis of potential multicollinearity, we assess the variance inflation factors (VIF) for all included variables. There is no objective standard to test whether there is "too much" multicollinearity using the VIF, but a conservative standard is that any variable with a VIF above 10 is highly collinear with other independent variables. The VIFs for the independent variables used are all below 8.9, well within the conservative standard. Thus, we do not believe that multicollinearity is a problem.

${ }^{36}$ For detailed information on outreach efforts, see Holt and Jamison (2006). See www.universalservice.org for stated goals of the Lifeline program and the Universal Service Fund.
} 
As expected, the coefficient on Percent Welfare is positive and significant, indicating that receiving government assistance of another form has a positive and significant effect on Lifeline participation. Since non-monetary costs of applying for welfare decrease with receipt of other welfare, this result is expected. Additionally, the positive coefficient could result from scale economies in marketing Lifeline, given that the Lifeline program is advertised at welfare agencies. Our result also might reflect the possibility that higher concentrations of households receiving government assistance could lead to more points of contact for eligible households, resulting in greater word-of-mouth advertising for the program. ${ }^{37}$

Lastly, we note that our yearly dummy variables, Year 2004 and Year 2005, are both positive and significant. We assert that this reflects the growing concern with and interest in promoting the program among both state regulators and telecommunications companies. As awareness of the program increases and methods by which households can enroll are improved, we expect this trend to continue as long as the benefits of the subsidy outweigh the costs of participation.

\section{Conclusion}

Telecommunications providers have a genuine interest in the rate of participation in the Lifeline program. Florida providers alone contributed over $\$ 18$ million in the year 2004 to the Lifeline program. However, the program presents companies with conflicting incentives. It is costly to provide discounts on customers' bills; therefore, companies have incentive to limit participation. ${ }^{38}$ On the other hand, companies must show support of low-income households for rate increases to be approved; therefore, companies have an incentive to increase participation.

\footnotetext{
${ }^{37}$ Recall that Percent Rural and Percent Welfare measure all households in a given county; thus, these measures may impact both the number of eligible households that participate and the total number of eligible households (i.e., both the numerator and the denominator of the Lifeline participation rate), and one must be circumspect when interpreting the results with respect to these variables.

${ }^{38}$ This is not to say that companies act on this incentive. There may be non-financial reasons for companies to promote Lifeline such as social concerns for public access to telecommunications.
} 
The key for telecommunications providers is to ensure that the Lifeline program effectively targets those households most in need of support. In terms of regulating efforts to target households, the FCC and FPSC give companies informal guidance: statutes require that efforts to publicize the program be reasonably designed to reach those likely to qualify. ${ }^{39}$ This research provides information for companies to more effectively promote the Lifeline program. For instance, companies may find that targeting rural households, renters, and older individuals will lead to increased participation. Some marketing could be relatively low cost. For example, in 2002 the FPSC partnered with the American Association of Retired Persons (AARP) to inform older households of the program. Currently in Florida AT\&T partners with United Way, the Foster Grandparent Program, and Catholic Charities, among other programs. Additionally, the FCC and the FPSC could tie proposed rate increases to such targeted marketing. Such changes in the implementation of the program may prove critical to the continuation of Lifeline, as studies increasingly evaluate the usefulness and efficiency of the program.

This leads to our final comment, that our research sheds light on a specific component of the much broader question of the need for a universal service program. The cost-effectiveness of subsidies and the type of subsidy that would most benefit the goal of universal residential telephone service should be considered in light of these results. Our research supports the findings of others with respect to household characteristics that are associated with increased participation in public assistance programs. Lifeline is to some extent targeted in the sense that it

\footnotetext{
${ }^{39}$ In the Federal-State Board on Universal Service, cc Docket No. 96-45, Recommended Decision, 18 FCC Rcd 6589 (2003), the Joint Board recommended that no specific federal outreach guidelines be set but that states and carriers retain the authority to implement guidelines as they see fit. The FPSC has a similar flexible framework that includes guidelines but no formal requirements. For example, the FPSC held a workshop addressing outreach efforts and worked to set objectives to increase participation (see "Know Your Florida Public Service Commission," available at http://www.floridapsc.com/publications; also, Docket No. 970744-TP, Order No. PSC-97-1262-FOFTP). General requirements apply unless a complaint is made against a company, after which specific guidelines are set for the offending company. To date, no complaints have been filed against telecommunications companies in Florida.
} 
focuses on low-income households (i.e., households who are most at risk of not affording telephone service). However, the discount is available to all low-income households, even those that would purchase telephone service without the discount. Therefore, this work supports the conclusion by others that the Lifeline program is costly and, as a subsidy that is only partially targeted, increasing the effectiveness of the program is exceedingly complicated. Additionally, if higher local phone rates do result in an increase in Lifeline participation, then higher local rates make the program even less targeted and therefore more costly. These questions should continue to be asked and analyzed on a broad scale so that the goal of universal service is evaluated practically, and if the goal is found to be useful, that it may be achieved in the most efficient possible manner. 


\section{Table 1}

County-Level Summary Statistics

$$
\mathbf{N}=\mathbf{2 0 1}
$$

Variable

Lifeline Subscribers Total Number of Lifeline Subscribers

Eligible Households Total Number of Eligible Households

$$
\ln \left(\rho_{i t} / 1-\rho_{i t}\right) \quad \text { Logit of the Lifeline Participation Rate }
$$

Percent BellSouth Percent of Telephone Service Provided by BellSouth

Percent Sprint Percent of Telephone Service Provided by Sprint

Percent Verizon Percent of Telephone Service Provided by Verizon

Local Phone Rate Average Monthly Charge for Single Residential Line

Cell Phones Average Number of Cell Phones per Household

Percent Own Home Percent of Eligible Households Owning Home

Percent No High School Percent of Eligible Households Not Finishing High School

Percent High School Percent of Eligible Households with High School Degree Only

Percent White Percent of Eligible White Heads of Households

Percent Female Percent of Eligible Female Heads of Households

Percent Age 25-54 Percent of Eligible Heads of Households Age 25 to 54

Percent Age 55-74 Percent of Eligible Heads of Households Age 55 to 74

Percent Age 75+ Percent of Eligible Heads of Households Age 75 and Up

Percent Rural Percent Rural Households

Percent Welfare Percent Households Receiving Government Assistance
Mean Std. Dev.

$2,186 \quad 6,039$

15,335 27,565

$-2.60 \quad 1.58$

$32.66 \quad 41.46$

$39.97 \quad 42.61$

$6.76 \quad 20.09$

$9.85 \quad 1.22$

$1.14 \quad 0.62$

$58.23 \quad 11.26$

$43.16 \quad 7.92$

$31.44 \quad 3.33$

66.53

15.19

54.39

4.57

44.57

6.07

29.17

4.86

17.32

41.16

33.64

2.60

\section{Data Sources}

Lifeline subscribers: BellSouth (BellSouth's Marketing Information System); Sprint (Sandy Khazraee); Verizon (Alan Ciamporcero); LECs (Thomas McCabe, TDS). Local rates, access lines, and cell phone usage: Florida Public Service Commission (Jeff Bates and Beth Salak). Lifeline eligibility: Shimberg Center for Affordable Housing, University of Florida (Anne Williamson). Other county-level measures: United States Census Bureau (US Census, 2005). 


\begin{tabular}{|c|c|c|c|}
\hline \multicolumn{4}{|c|}{$\begin{array}{c}\text { Table } 2 \\
\text { FGLS Results } \\
\text { Dependent Variable }=\text { Logit of Lifelin }\end{array}$} \\
\hline Variable & Coefficient & S.E. & $\begin{array}{c}\text { Marginal } \\
\text { Effect }\end{array}$ \\
\hline Percent BellSouth & $0.0022 * * *$ & $(0.0007)$ & 0.062 \\
\hline Percent Sprint & 0.0010 & $(0.0006)$ & 0.033 \\
\hline Percent Verizon & $0.0050 * * *$ & $(0.0008)$ & 0.029 \\
\hline Local Phone Rate & $0.0358 * *$ & $(0.0150)$ & 0.306 \\
\hline Cell Phones & $-0.1215 * * *$ & $(0.0370)$ & -0.120 \\
\hline Percent Own Home & $0.0513 * * *$ & $(0.0063)$ & 2.613 \\
\hline Percent No High School & $-0.0102 *$ & $(0.0054)$ & -0.381 \\
\hline Percent High School & $-0.0272 * * *$ & $(0.0093)$ & -0.741 \\
\hline Percent White & 0.0034 & $(0.0025)$ & 0.193 \\
\hline Percent Female & $0.0303 * * *$ & $(0.0056)$ & 1.438 \\
\hline Percent Age 25-54 & -0.0018 & $(0.0076)$ & -0.068 \\
\hline Percent Age 55-74 & 0.0083 & $(0.0091)$ & 0.211 \\
\hline Percent Age 75+ & $-0.0437 * * *$ & $(0.0109)$ & -0.654 \\
\hline Percent Rural & $-0.0188 * * *$ & $(0.0021)$ & -0.666 \\
\hline Percent Welfare & $0.5488 * * *$ & $(0.0317)$ & 1.219 \\
\hline Year 2004 & $0.0469 * * *$ & $(0.0009)$ & \\
\hline Year 2005 & $0.0505 * * *$ & $(0.0011)$ & \\
\hline Constant & $-5.976 * * *$ & $(0.6183)$ & \\
\hline $\begin{array}{l}\text { Psuedo- } \mathrm{R}^{2}=0.839 \\
* * * \text { Significant at } 1 \% \\
* * \text { Significant at } 5 \% \\
* \text { Significant at } 10 \%\end{array}$ & & & \\
\hline
\end{tabular}




\section{References}

Andrade, C., Faculdade de Ciencias Economicas e Empresariais. 2002. The economics of welfare participation and welfare stigma: a review. Public Finance and Management 2(2), 294333.

Blank, R. M., Ruggles, P. 1994. Short-term recidivism among public-assistance recipients. American Economic Review 84(2), 49-53.

Blundell, R., Fry, V., Walker, I. 1988. Modeling the take-up of means-tested benefits: the case of housing benefits in the United Kingdom. The Economic Journal 98, 58-74.

Burton, M., Macher, J., Mayo, J. W. 2007. Understanding participation in social programs: why don't households pick up the lifeline? The B.E. Journal of Economic Analysis and Policy 7, 126.

Currie, J. 2004. The take up of social benefits. National Bureau of Economic Research, Working Paper 10488.

Eriksson, R. C., Kaserman, D. L., Mayo, J. W. 1998. Targeted and untargeted subsidy schemes: evidence from postdivestiture efforts to promote universal telephone service. Journal of Law and Economics 41, 477-502.

Federal Communications Commission. 2005. Universal Service Monitoring Report, CC Docket No. 98-202.

Federal Communications Commission. 2004. Report and Order and Further Notice of Proposed Rulemaking, WC Docket 03-109, In the matter of Lifeline and Link-Up, Release No. FCC 0487, April 29.

Federal Communications Commission. 2003. Federal-State Joint Board on Universal Service, CC Docket 96-45, Recommended Decision, 18 FCC Rcd 6589.

Florida Public Service Commission. 2006. Know Your Florida Public Service Commission, Link-Up Florida and Lifeline Assistance Programs, available at www.floridapsc.com.

Florida Public Service Commission. 2004. In re: Adoption of the National School Lunch Program and an Income-based Criterion at or below $135 \%$ of the Federal Poverty Guidelines as Eligibility Criteria for the Lifeline and Link-Up Programs, Notice of Proposed Agency Action: Order Expanding Lifeline Eligibility, Docket No. 040604-TL, Order No. PSC-04-078 1-PAATL, August 10.

Florida Public Service Commission. 1997. Docket No. 970744-TP, Order No. PSC-97-1262FOF-TP. 
Florida Senate. 2004. Assessment of Lifeline Assistance Program, Interim Project Summary 2005-116, November.

Garbacz, C., Thompson, H. G. Jr. 2003. Estimating telephone demand with state decennial census data from 1970 - 1990: update with 2000 data. Journal of Regulatory Economics 24(3), 373-378.

Garbacz, C., Thompson, H. G. Jr. 2002. Estimating telephone demand with state decennial census data from 1970 - 1990. Journal of Regulatory Economics 21(3), 317-329.

Garbacz, C., Thompson, H. G. Jr. 1997. Assessing the impact of FCC Lifeline and Linkup programs on telephone penetration. Journal of Regulatory Economics 11(1), 67-78.

Greene, W. H. 2003. Econometric Analysis, Fifth Edition. Prentice Hall, Upper Saddle Ridge.

Hauge, J., Jamison, M. A., Jewell, R. T. 2007. Participation in social programs by consumers and companies: a nationwide analysis of participation rates for telephone lifeline programs. Public Finance Review 35(5), 606-625.

Holt, L., Jamison, M. A. 2006. Making telephone service affordable for low-income households: an analysis of Lifeline and Link-Up telephone programs in Florida. University of Florida, Public Utility Research Center, Working Paper.

Hoynes, H. W. 1996. Welfare transfers in two-parent families: labor supply and welfare participation under AFDC-UP. Econometrica 64(2), 295-332.

Maddala, G.S. 1983. Limited-Dependent and Qualitative Variables in Econometrics. Cambridge University Press, Cambridge, UK.

McGarry, K. 1995. Factors determining participation of the elderly in SSI. National Bureau of Economic Research, Working Paper 5250.

Moffitt, R. 1983. An economic model of welfare stigma. American Economic Review 73, 10231035.

Papke, L. E., Wooldridge, J. M. 1996. Econometric methods for fractional response variables. Journal of Applied Econometrics 11(6), 619-632.

Rodini, M., Ward, M. R., Woroch, G. A. 2003. Going mobile: substitutability between fixed and mobile access. Telecommunications Policy 27(5-6), 457-476.

Rosston, G. L., Wimmer, B. S. 2000. The "state" of universal service. Information Economics and Policy 12(3), 261-283.

Stuber, J., Kronebusch, K. 2004. Stigma and other determinants of participation in TANF and Medicaid. Journal of Policy Analysis and Management 23(3), 509-530. 
Tucker, C. J., Brick, M., Meekins, B. 2007. Household telephone service and usage patterns in the United States in 2004: implications for telephone samples. Public Opinion Quarterly 71(1), $3-22$.

United States Census Bureau. 2005. factfinder.census.gov. County-level Demographic Data. http://factfinder.census.gov/ (accessed August 1, 2005).

Valletti, T. M., Hoernig, S., Barros, P. P. 2002. Universal service and entry: the role of uniform pricing and coverage constraints. Journal of Regulatory Economics 21(2), 169-190.

Yelowitz, A. S. 2000. Public policy and health insurance choices of the elderly: evidence from the Medicare Buy-In Program. Journal of Public Economics 78(3), 301-324. 


\section{Endnotes}

1 Technically, eligibility is determined by household, not by subscriber. For convenience, we will generally refer to subscribers when referring to household telecommunications customers.

2 Data from the FCC's Monitoring Report, December 2005, Section 2.

3 The associated Link-Up program provides a one-time subsidy to households to offset the cost of initiating telephone service. Often the Lifeline and Link-Up programs are referenced together. In our paper we focus on the Lifeline program due to its recurring benefits.

4 For example, see Florida Senate (2004) for an assessment of the Lifeline program in 2004.

5 There are also concerns about the usefulness of the program for promoting universal service. We do not address this issue in this study.

${ }_{6}$ California instituted its own eligibility requirements including self-certification of eligibility, which resulted in their having greater than 100 percent of eligible households participating over the years $2002-2004$.

${ }_{7}$ Cellular providers are increasingly offering Lifeline discounts. For example, in Florida, Sprint /Nextel offers a discounted mobile phone plan to eligible low-income households. AT\&T wireless offers a similar plan in Louisiana, Mississippi, Washington, and Oregon.

${ }_{8}$ Wireline refers to the traditional method of providing telephone service, namely via telephone wires buried in the ground or strung on utility poles. This is also frequently called fixed line service because the line is not mobile, but fixed services may also be wireless. Subsidies for wireline services would be particularly unjustified if further research confirms that low-income households choose wireless telephone communications rather than wireline, all else equal.

${ }_{9}$ For example, within our study the enrollment procedures are equivalent across participating telephone companies. Additionally, there are no restrictions on supplementary services so that recipients can subscribe to call waiting, caller ID, and similar additional features while receiving Lifeline. Finally, the level of benefit is consistent throughout the state. Burton et al. incorporate each of these cross-state differences in their paper; however, these differences are not relevant to our work.

10 These surveys are available at www.purc.ufl.edu. In sum, the surveys found that lack of awareness and distrust of support programs for low-income households are significant barriers to enrollment. They also found that 88 percent of low-income households in Florida had wireline phones, about 50 percent had a cellular phone, about 50 percent had Internet access, and about 50 percent had either cable television or Direct Broadcast Satellite service.

$11 \mathrm{We}$ expect any stigma effect to be small. First, it is simple for participants to apply and they need not do so in person. Florida provides information on Lifeline in a customer's bill, along with a form requesting that the potential participant respond if he receives any of the other welfare programs which qualify him to receive Lifeline or to submit documentation of lowincome. The potential participant does not need to visit an agency or deal with social workers, nor does he have to publicly claim this benefit; it simply appears as a credit on his telephone bill each month. Such anonymity should decrease the stigma effect. Also, if the marginal disutility of enrolling decreases with participation in another program and if the primary way of qualifying for Lifeline is by showing receipt of other welfare, it seems logical that the cost of enrolling in Lifeline should be lower than the cost of enrolling in other welfare programs.

12 These funds come from fees assessed on telecommunications providers.

13 All ILECs are designated eligible telecommunications carriers; they provide Lifeline and are entitled to receive Federal support. Eligible telecommunications carrier status may also apply to wireless service providers whose petitions for such status have been approved by the FCC and to competitive local exchange carriers whose petitions have been approved by the FPSC. To date, the FCC has designated three wireless providers to serve as eligible telecommunications carriers in Florida - Nextel Partners, Sprint, and Alltel. The FPSC has designated two competitive local exchange carriers, Knology and Budget Phone, as eligible telecommunications carriers in Florida.

14 Basic local telephone service includes unlimited local area calling. The Lifeline program does not prohibit consumers from purchasing additional services such as call waiting or caller ID if they wish.

15 The federal default eligibility criteria are used if a state does not establish its own eligibility criteria. Prior to this FCC decision, the federal default eligibility criteria required the customer to participate in at least one of the following federal programs: Medicaid, Food Stamps, SSI, FPHA, or LIHEAP (or to have income 125\% FPG). Small ILECs in Florida do not use the NSL program as an eligibility criterion for Lifeline.

${ }_{16}$ The small ILECs may choose to remain at 125 percent FPG. The 135 percent criterion became effective by the end of 2005. With respect to the new certification and verification procedures and outreach guidelines, Florida's ILECs were in compliance. 
${ }_{17}$ Link-Up is the federal program providing a credit for telephone hook-up service. Often the Lifeline and Link-Up programs are referred to simultaneously as they have the same goal of increasing telephone penetration in lowincome areas. The primary difference is that Lifeline is a monthly credit, whereas Link-Up applies only at telephone installation. This study addresses only the Lifeline program.

${ }_{18}$ Statistics are available at http://www.purc.ufl.edu/Lifeline2.htm.

19 Twenty-five states had higher participation rates than Florida during the years of our study (Hauge et al., 2006); while Florida's actual participation rate of $17.57 \%$ places it at the median, Florida's participation rate is below the national average participation rate of $23.16 \%$.

${ }_{20}$ Qualifying households receive the Lifeline discount on only one telephone line. Therefore second connections and prices for second connections are part of the composite good $\mathrm{Z}$.

${ }_{21}$ Burton et al. (2007) include an explanation in which the consumer surplus of various households is modeled to illustrate households for whom the level of benefit is relevant. Specifically, they illustrate that there are some households who are not willing and able to sign up for telephone service at all given a particular benefit level. There are other households who are willing and able to sign up for telephone service given that same level of benefit, and those who will subscribe to telephone service without Lifeline (even if they qualify). It is this category of eligible households whose decision not to subscribe is in question.

22 The number of Lifeline participants is provided by each company at the city level. We aggregate to the county level to correspond to the level of the eligible household data.

23 The weights are $1 /\left[n_{i} p_{i}\left(1-p_{i}\right)\right]$, where $n_{i}$ is the total eligible households of county $i$, and $p_{i}$ is the logit probability of the Lifeline participation rate in county i. As discussed by Greene (2003, p.677-688), pi must be estimated since it is a function of unknown parameters. Following the prescribed procedure, we estimate pi using ordinary least squares (OLS) in a first stage because all that is needed is a consistent estimate of $\mathrm{p}_{\mathrm{i}}$. The weights are then computed and used in a second-stage feasible generalized least squares estimation. Several specifications of the dependent variable are available. We choose the minimum logit chi-square estimator due to its similarity to the well-known logit dichotomous choice model. To test robustness, we estimated the model using another commonly employed specification in which the dependent variable is simply the log of the participation rate, finding no major differences between the two specifications. There are 13 year/county observations with zero subscribers. Rather than delete these observations, the number of subscribers is arbitrarily assigned to one in order to compute the dependent variable. Although clearly ad hoc, this solution is the most viable in our situation. We also include a dummy variable in our estimation to account for the 13 observations; the dummy variable (not reported for brevity) is significantly negative.

24 Some county-level Lifeline participation data are available back to 2000; however, prior to 2003 data is incomplete. We choose to analyze the most-recent three years since they represent complete panels. Summary statistics for 2000-2005 are available from the authors.

25 A Hausman test indicates that the assumption of the random effects model concerning the orthogonality of the random effects and the regressors is appropriate. The chi-square statistic (15 d.f.) is 20.88 , which is insignificant at any conventional level. Thus, we cannot reject the null of no correlation between the random effects and the regressors. Complete results of this test are available from the authors. We choose the random effects model because it allows the inclusion of time-invariant regressors and is more efficient than a fixed-effects model.

${ }_{26}$ The error term $\varepsilon_{j t}$ might be serially correlated. The standard errors for the estimation may be affected and should be viewed with some caution.

27 The telecommunications environment measures are gathered from the FPSC's "Annual Report to the Florida Legislature on the Status of Competition in the Telecommunications Industry in Florida" from which the number of access lines per company and the local single residential line rate per exchange were obtained, and cell phone subscribership per county was provided directly by staff at the FPSC. The excluded category includes smaller providers: Alltel, Frontier Communications of the South, ITS Telecommunications, Northeast Telephone Company dba NEFCOM, and TDS Telecommunications/Quincy Telephone.

28 Taxes are not included in the Local Phone Rate variable. This means Local Phone Rate ranges from $\$ 6.30$ to $\$ 12.10$ with a mean of $\$ 9.80$. Taxes may include Federal/State Subscriber Line charges, Universal Service Fund charges, Primary Interexchange Carrier Charges, and Local Number Portability charges. As explained in the description of the origins of Lifeline credits, the Lifeline subsidy is designed to remove these taxes from bills of eligible participants; thus, eligible households should pay only the local phone rate. While our theoretical model references a price of Lifeline that includes the subsidy, the subsidy does not vary by county. Therefore, it is appropriate to include Local Phone Rate as the proxy for price. Also, the Lifeline subsidy is not included in the estimation. 
29 Mark Jamison, Presentation to the Florida Public Service Commission, February 27, 2006, available online at www.cba.ufl.edu/purc.

30 This is termed "peer group stigma effect" by Blundell et al., 1998, who argue that associating with more educated individuals leads one to believe that he or she should not need public assistance but should be intelligent and motivated enough to provide for oneself. Therefore while more educated people might know of the Lifeline program, they might believe that it is for those unable to provide for themselves, not for well-educated individuals with skills to support themselves.

31 Approximately 9.8 million of 11.9 million single parents in the US are women (www.singleparent.com).

32 The model also includes yearly dummies (coefficients are not reported for brevity) to indicate a time trend in Lifeline participation that is common to all counties. The results (available from the authors) indicate that a positive shift in the participation rate occurred after 2003.

33 We report the Wald chi-square test statistic on the three provider variables: $\operatorname{chi} 2(3)=81.86$, Prob $>$ chi2 $=0.0000$, indicating that the coefficients are jointly significant at the $1 \%$ level.

34 The positive coefficient for Local Phone Rate may also be due to omitted variable bias. It has been suggested that such a result could occur if telephone service is more valuable to lowincome households in counties where the local phone rate is higher, and therefore more eligible households subscribe to Lifeline service rather than declining all service. Additionally, the positive correlation between Local Phone Rate and the population-weighted average local calling area in a county $(0.5215)$ may contribute to this result.

35 In other versions of the model, we control for percent white, percent black, percent Hispanic, and all other races. The results (available from the authors) show insignificant coefficients on all racial categories. As an analysis of potential multicollinearity, we assess the variance inflation factors (VIF) for all included variables. There is no objective standard to test whether there is "too much" multicollinearity using the VIF, but a conservative standard is that any variable with a VIF above 10 is highly collinear with other independent variables. The VIFs for the independent variables used are all below 8.9, well within the conservative standard. Thus, we do not believe that multicollinearity is a problem.

${ }_{36}$ For detailed information on outreach efforts, see Holt and Jamison (2006). See www.universalservice.org for stated goals of the Lifeline program and the Universal Service Fund.

${ }_{37}$ Recall that Percent Rural and Percent Welfare measure all households in a given county; thus, these measures may impact both the number of eligible households that participate and the total number of eligible households (i.e., both the numerator and the denominator of the Lifeline participation rate), and one must be circumspect when interpreting the results with respect to these variables.

38 This is not to say that companies act on this incentive. There may be non-financial reasons for companies to promote Lifeline such as social concerns for public access to telecommunications.

39 In the Federal-State Board on Universal Service, cc Docket No. 96-45, Recommended Decision, 18 FCC Rcd 6589 (2003), the Joint Board recommended that no specific federal outreach guidelines be set but that states and carriers retain the authority to implement guidelines as they see fit. The FPSC has a similar flexible framework that includes guidelines but no formal requirements. For example, the FPSC held a workshop addressing outreach efforts and worked to set objectives to increase participation (see "Know Your Florida Public Service Commission," available at http://www.floridapsc.com/publications; also, Docket No. 970744-TP, Order No. PSC-97-1262-FOFTP). General requirements apply unless a complaint is made against a company, after which specific guidelines are set for the offending company. To date, no complaints have been filed against telecommunications companies in Florida. 